\title{
精細胞の動態から迫る重複受精機構
}

\author{
浜村有希 \\ 名古屋大学大学院理学研究科GCOEライブイメージングセンター $\bar{T} 464-8602$ 名古屋市千種区不老町 \\ 名古屋大学生物機能開発利用研究センター ₹ 464-8601 名古屋市千種区不老町
}

\begin{abstract}
要旨 : 重複受精は被子植物に特徵的な生殖機構であり, 農業的にも意義があるだけでなく生物学的にも大変興味 深い現象である. 1 つ花粉に 2 つる精細胞のうち一方が卵細胞と受精して胚となり，もう一方が卵細胞の隣にあ る中央細胞と受精して胚の栄養器官となる胚乳を形成する. これまで重複受精過程の精細胞の動態は捉えられて

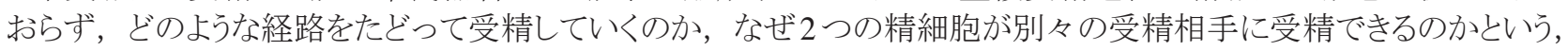
根本的な疑問が解決されていない。この 10 年間のライブイメージング技術の発達により，これまで謎に包まれてい た重複受精過程の精細胞の動きが明らかにされた。本総説では, 精細胞の動態に着目したライブイメージング解析 と分子遺伝学的解析を組み合わせて花粉管の内容物放出から配偶体の融合までの重複受精過程について述べたい.
\end{abstract}

\section{Double fertilization mechanism as suggested by sperm cell dynamics}

\section{Yuki Hamamura}

Graduate School of Science, Nagoya University, Furo-cho, Chikusa-ku, Nagoya 464-8602, Aichi, Japan

\begin{abstract}
Summary: Double fertilization is a one of the remarkable features in angiosperms. A pollen grain contains two sperm cells. One of the two sperm cells fertilizes the egg cell to produce embryo. Another sperm cell fertilizes the central cell to produce an endosperm which supplies nutrient to the embryo. The movement of the sperm cells during double fertilization was never caught before. Therefore, basic questions for double fertilization, such as what are paths of sperm cells to reach target female gametes and why two sperm cells can fertilize different partners are not resolved. In this decade, technical innovation of live-cell imaging has enabled to reveal the sperm cell movement during double fertilization. In this review, we discuss the double fertilization process from pollen tube discharge to gamete fusion, focusing on sperm cell movement by live-cell imaging and molecular genetic approaches.
\end{abstract}

Key words: double fertilization, live-cell imaging, sperm cell

\section{はじめに}

被子植物の花粉は2つの精細胞をもち，2つの助 細胞と卵細胞，中央細胞を含む雌性配偶体まで花粉 管を伸ばして精細胞を運ぶ（図 1)。花粉管が此性配 偶体まで正確に誘引される花粉管ガイダンスについて は，胚囊が胚珠組織から裸出したトレニアや，モデル 植物のシロイヌナズナ, トウモロコシを用いた研究より, 助細胞で発現している分泌性のCRPs (Cysteine-rich peptides)の関与が明らかになってきている (Takeuchi et al. 2011, Dresselhaus et al. 2011). 此性性配偶体に誘引 された花粉管は，助細胞の細胞壁からなる線形装置と 呼ばれる構造に接触する。 そして，花粉管は精細胞を

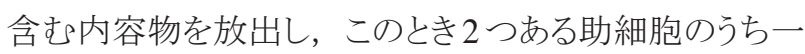
方の助細胞が崩壊する. その後, 1 つの精細胞が卵 細胞と受精し, もう1つの精細胞が中央細胞と受精する. 受精後, 卵細胞は次世代を担う胚になるが，その一方 で中央細胞は胚発芽の栄養となる胚乳を形成する.こ
のように2つの受精からなる現象であることより，被子植 物の生殖過程は「重複受精」と呼ばれている.

Nawashin (1898) と Guignard (1899) による重複受精 の発見以来, 多くの植物学者が固定試料や切片を用 いてこの現象を追ってきた。これは，胚囊が肧珠組織 に埋め込まれた状態で雌ずいの奥深くに位置しており, 直接観察することが困難であったためだ。しかしながら， このような固定試料を用いた観察では，重複受精にお ける精細胞の動態はほとんど明らかにされず，自ら動 けない $2 つ の$ 精細胞がどのような経路をたどって，どれ くらいの時間で受精していくのか, また別々の受精相 手の細胞に受精できるメカニズムは?といった, 多くの 疑問が残されたままである.

近年，ライブイメージング技術の進歩により，重複受 精過程における雌雄間の配偶体における相互作用が 生きたまま可視化できるようになってきた (Hamamura et al. 2012). 本レビューでは，主にシロイヌナズナの精 


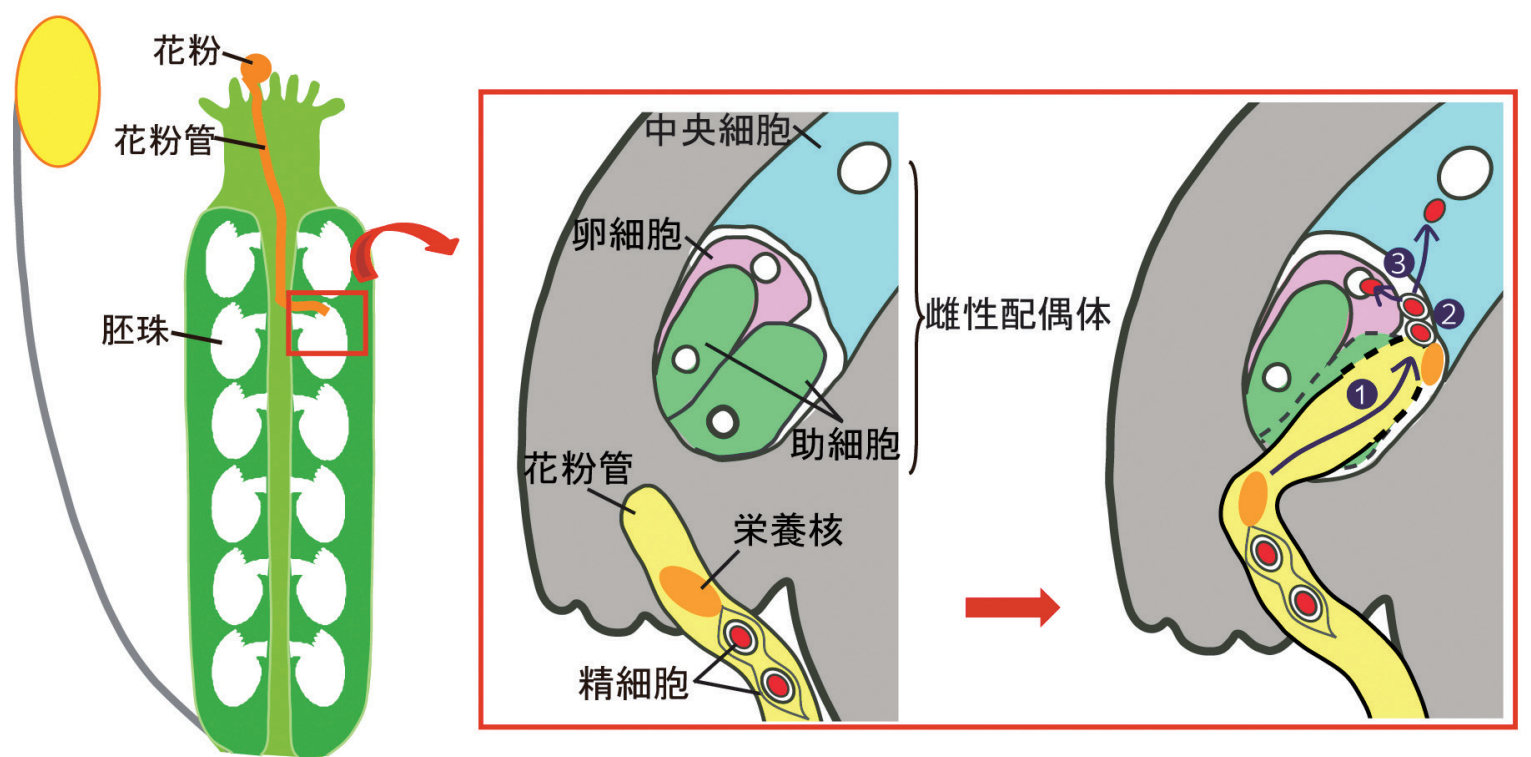

図 1 重複受精に関わる配偶体細胞の模式図

雌ずいに付いた花粉は花粉管を伸ばして精細胞を肧珠に埋め込まれた雌性配偶体まで運ぶ.2つある精細胞は一 方が卵細胞と受精してもう一方が中央細胞と受精する (重複受精)。花粉管内容物の放出から受精までの精細胞の 動態を観察すると, 右の図に示す3段階の動きが見られた.

細胞の動態に着目して, ライブイメージング解析と分子 遺伝学的解析による報告を概説しながら, 花粉管の内 容物放出から配偶体の融合までの重複受精過程につ いて議論する.

シロイヌナズナにおける重複受精のライブイメージン グにより, 花粉管の内容物放出からの精細胞の動態 には3 段階の動きがあることを明らかにされた（図 1 ; Hamamura et al. 2011)．初めの第1段階では，精細胞 が数秒で花粉管から雌性配偶体内一と運ばれる．その 後，第2段階には，運ばれた精細胞が雌性配偶体内 で数分間留まり, 移動しないステップがあり, その後, 精細胞はそれぞれの受精相手の細胞と融合していく第 3段階が見られた．以下に，これらのステップに基づい て重複受精機構について議論していく.

\section{第 1 段階 : 花粉管内容物の放出と精細胞の輸送}

我々は, Semi-in vitro 受精系を用いた観察によって, 顕微鏡下で生きたまま重複受精過程を観察することに 成功した. 重複受精における精細胞の動態の第 1 段階 として, まず花粉管内容物の放出と精細胞の運搬がある. 精細胞は花粉管の内容物放出開始から約 8 秒というご く短い時間で花粉管から雌性配偶体の中まで輸送され ていた. 自然受粉後の固定サンプルや切片観察によ る以前の報告では，2つの精細胞は崩壊した助細胞の
なかを珠孔端から頂端まで徐々に輸送されていくといっ た説が提唱されていた (Wallwork and Sedgley 2000, Ye et al. 2002, Tian et al. 2005). 生きた状態で観察するこ とにより，予想をはるかに上回る速さで精細胞が輸送 されていることが初めて明らかになった。この急速な精 細胞の輸送を生み出す駆動力が何であるかは，非常 に興味深い問題であるが，詳細は未だ明らかにされて いない.いくつかの植物種においては, ‘コロナ’と呼 ばれる崩壊した助細胞中のアクチンケーブルが，アク チンーミオシン系によって精細胞をターゲッ細胞まで運 んでいる可能性が示唆されてきた (Huang and Russell 1994, Mol et al. 1994, Huang and Sheridan 1998, Huang et al. 1999). しかしながら, 崩壊した助細胞に由来す るアクチンケーブルが細胞外で機能できるという点には 疑問が残る。胚囊が胚珠組織から裸出したトレニアを 用いたライブセル解析により，花粉管内容物が放出によっ て勢いよく胚囊内に送り込まれる様子が観察されている (Higashiyama et al. 2000).シロイヌナズナにおける放 出時の精細胞の動きと, トレニアの放出時の花粉管内 容物の動きを合わせて考えると，精細胞の運搬は花粉 管内容物の流れによって押し出されている，受動的な 動きである可能性が考えられる.

花粉管内容物の放出が起こるとき, 2 つの助細胞の うち1つが崩壊することはよく知られている。しかし，花 

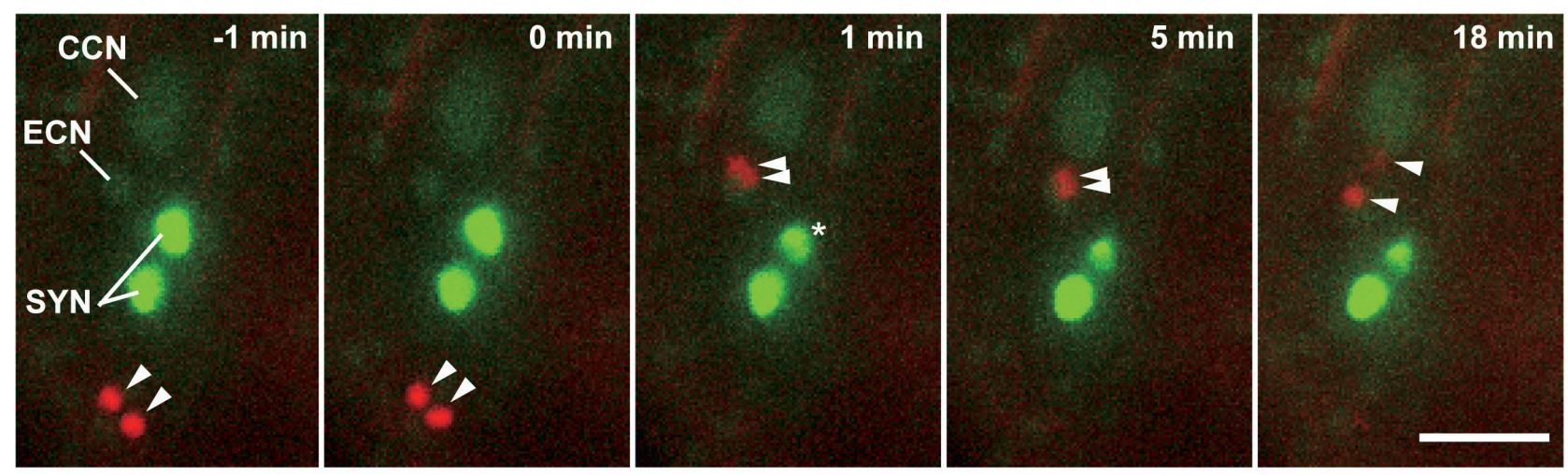

図 2 ライブセルイメージングによって観察された重複受精過程の精細胞の動き

精細胞は 1 分以内に胚囊内一と輸送され ( $0 \mathrm{~min}, 1 \mathrm{~min})$, しばらくその場に留まり $(5 \mathrm{~min})$, その後受精していく (18 min). 2 つ の精細胞核を矢尻で示し，崩壊した助細胞の核を*で示した。SYは助細胞の核を，ECNは卵細胞核を，CCNは中央細胞 核を表している.バーは $20 \mu \mathrm{m}$.

粉管の到着と助細胞の崩壊のタイミングは長年, 議 論されてきた。最近のシロイヌナズナにおける解析 で, 助細胞の崩壊は花粉管の雌性配偶体到着後で内 容物放出前であると示唆されてきた (Faure et al. 2002, Sandaklie-Nikolova et al. 2007). しかし, 我々が行っ たライブセルイメージングによって, 助細胞の崩壊は花 粉管の雌性配偶体到達後で内容物放出直後であること が明らかとなった (Hamamura et al. 2011)。この結果は, 遺伝学的解析にも支持されている. 最近の報告に助細 胞と花粉管のダイレクトな相互作用が花粉管の内容物 放出を引き起こす，といらものがある.レセプター様キナー ゼのFERONIAと，うどん粉病而性に関わる膜たんぱく 質MLOファミリーのNORTIAは花粉管の到着後に助細 胞の珠孔端側に局在し, 花粉管と助細胞の相互作用 に関わって花粉管の放出を引き起こすことが分かった (Huck et al. 2003, Rotman et al. 2003, Escobar-Restrepo et al. 2007, Capron et al. 2008, Kessler et al. 2010). 興味深いのは, FERONIAのホモログのANXUR1と ANXUR2 が花粉管の先端の細胞膜で発現しているこ とである. さらに，これらの二重欠損変異体では，雌 性配偶体にたどり着く前に花粉管の放出が起きてしま う(Miyazaki et al. 2009, Boisson et al. 2009)。これによ り, ANXUR1，2の不活性化が雌性配偶体内一の内容 物放出に重要であると考えられており，FERONIA依存 的シグナル経路とANXURに依存的なシグナル抑制が, 助細胞の崩壊と花粉管の放出のタイミングを調整してい ると考えられている.

\section{第 2 段階 : 2 つの精細胞の停止期}

花粉管内容物の放出による精細胞の䧳性配偶体内 への急速な運搬後, 精細胞はその場におよそ $7.4 \pm 3.3$ 分 $(\mathrm{n}=44)$ の間留まることが分かった (Hamamura et al. 2011)。この精細胞が留まっている場所と卵細胞, 中 央細胞の位置関係を詳細に解析寸るため, 2 光子顕微 鏡観察を行った. 2 光子顕微鏡は, 組織透過性の高 い長波長レーザーを用い深部の観察に適しており，焦 点面しか励起されないため, 周囲へのダメージを抑え てイメージングできるといら特徴がある。これにより，放 出後の精細胞が助細胞と卵細胞の頂端側の中央細胞 との境界に運ばれていることが分かった．精細胞はこの 境界領域で卵細胞と中央細胞の両方に接しておよそ7.4 分留まっていた (Hamamura et al. 2011)。この動きを留 める意義とは一体何だろう。トウモロコシの単離した卵 細胞，精細胞によるin vitro受精系では，受精前の卵 細胞と精細胞の接着に要する時間は約 3.8 分であると 示されている (Faure et al. 1994)。この停止期といらの は, ターゲットの細胞に受精するための精細胞や卵細胞, 中央細胞の準備に重要なのではないか.

\section{第3段階 : 精細胞の受精}

重複受精を保障するメカニズムとして考えられている モデルの一つに多精拒否モデルがある (Spielman et al. 2008）。これは，卵細胞と中央細胞のいずれか一方で より強い多精拒否バリアがあり, 残りの精細胞が受精し ていないもう一方の雌性配偶体細胞としか受精できない とするアイデアである. これを支持する変異体による解 
析がいくつか報告されている．2つの卵細胞と受精でき ない中央細胞を持つ rbr1変異体の肧珠では2つの野

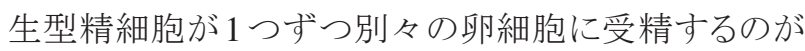
確認され，受精した卵細胞における多精拒否が示唆さ れた (Ingouff et al. 2004). Spielman と Scott (2008)は, 精細胞が多くできるtetraspore変異体において，花粉 管内の過剩な精細胞が常に中央細胞と受精することを 見つけた。この観察は，受精した卵細胞による，より 㛜密な強い多精拒否, つまり，卵細胞の受精が中央 細胞の受精より先に起こる可能性を提示した.

ライブセルイメージングでは, 7.4 分の小休止の後, 精細胞が，野生型特異的に雌性配偶体の核を目指し て移動を再開していた。これに対して，精細胞で発現 し受精に必須な細胞膜タンパク質 GCS1 の変異体では, 精細胞が䧳性配偶体の核に向かって移動しなかった。 これと，停止期には卵細胞と中央細胞の境界に存在す るということを合わせて考えると，精細胞の移動の再開 は受精を示すと考えることができる．停止期後に精細 胞が再び動き始めるタイミングを 2 光子顕微鏡を用いて 詳細に観察したところ，確かに，再び動き始める時に 中央細胞の細胞質に精細胞核が入っていたので，こ の受精のタイミングの定義は正しいと思われる.

そこで，重複受精機構を説明する多精拒否モデル について検証するため, 我々は, 卵細胞と中央細胞, 2つの受精に要した時間を前述の受精のタイミングで評 価し解析を行った。すると, 卵細胞と中央細胞の受精 に明確な順番は存在しなかったのである。つまり，半 数の例では卵細胞が先に，他の半数の例で中央細胞 が先に受精していた。受精の間隔は平均で $2.5 \pm 1.7$ 分で, 1 分間隔のタイムラプス観察では同時に受精す る例も見られた (Hamamura et al. 2011).これによって, 重複受精は受精した卵細胞からの単純な多精拒否によっ て保障されているわけではないといらことを示した。また， 融合のタイミングについて調べてみると, 卵細胞と中央 細胞の受精に要する時間には正の相関が見られた。こ の相関は，精細胞とターゲッ下細胞との接着している時 間の相関とも捉えることができ，2つの精細胞間や卵細 胞，中央細胞間での細胞間コミュニケーションがある可 能性を示唆している．つまりこれは，2つの精細胞がそ れぞれ独立して受精していくわけではない可能性を示 唆している.

$2 つ の$ 精細胞は，花粉の発生過程においてエンドサ
イトーシスによって取り込まれた膜に包まれ，栄養核と つながっており，雄性生殖単位を形成している(図 1) (Mogensen 1992)。いつ2つの精細胞がこの膜から離 れて直接配偶子間の相互作用できるようになるかは， 重要なポイントとなってくるだろう.

そして前述のGCS1の機能解析も非常に重要である. この GCS1 は植物だけでなく，原生生物にも保存され ている保存性の高い配偶子融合に必須の因子であるか らだ (Hirai et al. 2008). 最近の GCS1 のドメイン解析に よると， $\mathrm{N}$ 末端は配偶子の認識と融合に重要であると示 された (Mori et al. 2010, Wong et al.2011)．そして, C 末端は変異解析により，正に帯電している領域で，精 細胞の細胞膜と電気的に作用しているといらことが示唆 された (Wong et al. 2011). しかしながら，䧳性配偶体 側のパートナー分子や，コファクターはシロイヌナズナ において同定されておらず，配偶体の認識から融合に 至るまでのメカニズムについては，未だに明らかでない。 クラミドモナスでは，マイナス接合型特異的な GCS1 は配偶子融合の完了に必須であり，興味深いことに， GCS1 は膜融合後速やかに分解されていた. この速や かな分解は，他の配偶子による多精を避けるための仕 組みかもしれない(Liu et al. 2008).シロイヌナズナに おいては, 受精後の急速な分解は確認されていないが, ライブセルイメージングによって受精直後を観察するこ とで，受精後のGCS1の挙動が明らかになると期待され る.

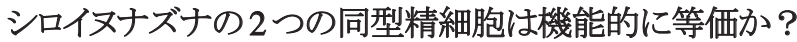

2つの精細胞は受精相手によって，その後全く異な る発生運命をたどる. 重複受精後，1つの精細胞は次 世代を担う胚を作るのに関わり，もう一方の精細胞は胚 に栄養を供給する胚乳形成に関わる．受精相手の細 胞があらかじめ決まっているのかは，長年議論されてき た (Knox et al.1993). ルリマツリ属のようないくつかの 植物では，2つの異型精細胞が常に同じ並びで雄性生 殖単位を形成していることが分かっている (Russell and Cass 1981, Sodmergen et al. 1995, Saito et al. 2002). ルリマツリの小さい方の精細胞 (栄養核とつながってい ない方）はプラスチドを多く含み, 卵細胞と受精しやす い(17例中 16例)（Russell 1985）。雄性生殖単位は被 子植物において一般的に見られる構造なので, このよ うな偏りのある受精が，シロイヌナズナのように同型の 
精細胞をもつ大部分の被子植物においても起きている かぞうかが焦点となっていた.

シロイヌナズナの変異体解析によるデータは, 混沌 としていて，受精に偏りがあるか結論付けられていな い. 例えば, eostre Prbrl 変異体の雌性配偶体内の 2つの卵細胞は，2つ野生型の精細胞とそれぞれ受精 することができ，これにより中央細胞としか受精できな い精細胞はないといらことが明らかになった (Ingouff et al. 2009, Pagnussat et al. 2007). 1つの精細胞様細胞 を持つ msil 変異体や $c d k a ; 1$ 変異体では, 卵細胞とも 中央細胞とも単一の受精を行う (Chen et al. 2008, Aw et al. 2010). しかしながら，ジフテリアトキシンAサブユ ニットを発現させて転写抑制を行って1つの精細胞様 細胞を形成させた時には, 中央細胞と受精しやすいと いう結果が得られている (Frank and Johnson 2009)，精 細胞特異的な cis-nat-siRNA であるkokopelli 変異体で も単一受精が見られるが，2つのうちの1つの精細胞は 卵細胞とも中央細胞とも受精寸る (Ron et al . 2010)。こ れらの精細胞の受精能力についての議論は, 変異体 に基づく解析であり，それゆえに，野生型では一体ど うなっているのか，その解析が期待されていた。

我々は，蛍光変換タンパク質 mkikGRを用いて花粉

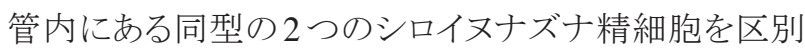
した (Hamamura et al. 2011)。この染め分けたWT精細 胞の重複受精は, 雄性生殖単位内で前に位置する(栄 養核につながった) 精細胞も, 後ろに位置する精細胞 も, 同程度に卵細胞と精細胞に受精しうることを証明した。 これは, シロイヌナズナにおいて, 受精相手は花粉管 内の位置よって偏りはないということを示している.

この結果は，融合に偏りがないという大部分の変異 体解析による結果と, シロイヌナズナの 2 つの精細胞で 偏りを持って発現している遺伝子が発見されていない ことと一致している．例えば，受精卵の不等分裂の制 御に必要なSHORT SUSPENSORは, 両方の精細胞 において転写されている (Bayer et al. 2009)。ルリマッ リ属で片側の精細胞特異的に発現する遺伝子の木モロ グは，シロイヌナズナにおいては2つの精細胞で均等 な発現が見られている (Ge et al. 2011).

一方で, 精細胞のエピジェネテイックな制御やリプロ グラシングについて，熱心に研究されている (Feng et al. 2010, Ingouff et al. 2007, Slotkin et al. 2009, Autran et al. 2011, Baroux et al. 2011, Wolff et al. 2011).これま
でに2 つの精細胞のうち一方にしか見られないエピジェ

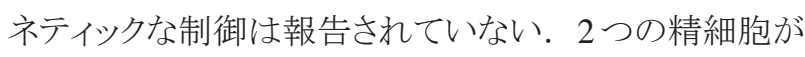
胚発生と胚乳形成の両方に適したエピジェネテイックな 制御を受けているのか興味が持たれる。また，2つの 精細胞核クロマチンは, 受精後に異なるリプログラミン グ (クロマチンリモデリング) を受けることが分かっている (Ingouff et al. 2007).これは, 2つの精細胞が機能的 に同等である場合に，それぞれ別々の相手と受精後に なぜ異なる発達プログラムに寄与できるかに対する一つ の答えなのかもしれない.

\section{おわりに}

ライブセルイメージングと分子遺伝学的解析が推し進 められているものの, 結局のところ, 重複受精におい て2つの精細胞が確実に異なる相手と受精する仕組み については謎のままである.この重複受精の仕組みに アプローチ寸るためには，精細胞が留まっている約 7.4 分の間の雌雄間相互作用に迫る必要がある. 更なるイ メージング技術の発展は, 高い時空間分解能におけ る情報を得る，非常に強力なツールとなるだろう。これ に加えて, 蛍光タンパク質で配偶体をラベルした可視 スクリーニング (Ikeda et al. 2011) や, 各配偶体で発現 する転写産物の大規模解析 (Borges et al. 2008, Qin et al. 2009, Wuest et al. 2010, Wang et al. 2010) を含むア プローチは，重複受精に関わる新しい遺伝子の単離を 加速させるだろう. 近い将来, これらの新しい知見が, 長い間謎に包まれてきた，重複受精機構に関する理 解を大きく進めることが期待される.

\section{謝辞}

奨励賞の受賞に至った本研究は, 日本学術振興会 (JSPS) による助成 (No. 9138)を受けて行われた。研 究生活において，昼夜を問わず熱くご指導いただい た名古屋大学の東山哲也教授, 佐々木成江准教授, 金岡雅浩助教, 共同研究者のFrederick Berger博士 (Temasek Life Sciences Laboratory)，たくさんのご助言 をいただいた栗原大輔特任助教 (ERATO 東山ライブホ ロニクスプロジェクト), 植田美那子助教 (奈良先端大 学院大学), マーカーライン分与と共焦点顕微鏡の使 用にご協力いただいた, 齊藤知恵子博士 (理化学研 究所), 中野明彦教授 (東京大学, 理化学研究所), 平野達也博士 (理化学研究所), いつも温かくサポー 
卜して下さった名古屋大学理学部東山研究室の皆様に 深くお礼申し上げたい.

\section{引用文献}

Autran, D., Baroux, C., Raissig, M. T., Lenormand, T., Wittig, M., Grob, S., Steimer, A., Barann, M., Klostermeier, U. C., Leblanc, O., Vielle-Calzada, J. P., Rosenstiel, P., Grimanelli, D., and Grossniklaus, U. (2011). Maternal epigenetic pathways control parental contributions to Arabidopsis early embryogenesis. Cell 145: 707-719.

Aw, S. J., Hamamura, Y., Chen, Z., Schnittger, A., and Berger, F. (2010). Sperm entry is sufficient to trigger division of the central cell but the paternal genome is required for endosperm development in Arabidopsis. Development 137: 2683-2690.

Baroux, C., Raissig, M. T., and Grossniklaus, U. (2011). Epigenetic regulation and reprogramming during gamete formation in plants. Curr Opin Genet Dev 21: 124-133.

Bayer, M., Nawy, T., Giglione, C., Galli, M., Meinnel, T., and Lukowitz, W. (2009). Paternal control of embryonic patterning in Arabidopsis thaliana. Science 323: 1485-1488.

Boisson-Dernier, A., Roy, S., Kritsas, K., Grobei, M. A., Jaciubek, M., Schroeder, J. I., and Grossniklaus, U. (2009). Disruption of the pollen-expressed FERONIA homologs ANXUR1 and ANXUR2 triggers pollen tube discharge. Development 136: 3279-3288.

Borges, F., Gomes, G., Gardner, R., Moreno, N., McCormick, S., Feijo, J. A., and Becker, J. D. (2008). Comparative transcriptomics of Arabidopsis sperm cells. Plant Physiol 148: $1168-1181$.

Capron, A., Gourgues, M., Neiva, L. S., Faure, J. E., Berger, F., Pagnussat, G., Krishnan, A., Alvarez-Mejia, C., VielleCalzada, J. P., Lee, Y. R., Liu, B., and Sundaresan, V. (2008). Maternal control of male-gamete delivery in Arabidopsis involves a putative GPI-anchored protein encoded by the LORELEI gene. Plant Cell 20: 3038-3049.

Chen, Z., Tan, J. L., Ingouff, M., Sundaresan, V., and Berger, F. (2008). Chromatin assembly factor 1 regulates the cell cycle but not cell fate during male gametogenesis in Arabidopsis thaliana. Development 135: 65-73.

Dresselhaus, T., Lausser, A.,and Marton, M. L. (2011). Using maize as a model to study pollen tube growth and guidance, cross-incompatibility and sperm delivery in grasses. Annals of Botany 108: 727-737.

Escobar-Restrepo, J. M., Huck, N., Kessler, S., Gagliardini, V., Gheyselinck, J., Yang, W. C., and Grossniklaus, U. (2007). The FERONIA receptor-like kinase mediates male-female interactions during pollen tube reception. Science 317: 656660.

Faure, J. E., Digonnet, C., and Dumas, C. (1994). An in vitro system for adhesion and fusion of maize gametes. Science 263: 1598-1600.

Faure, J. E., Rotman, N., Fortune, P., and Dumas, C. (2002). Fertilization in Arabidopsis thaliana wild type: developmental stages and time course. Plant J 30(4): 481-
488.

Feng, S., Jacobsen, S. E., and Reik, W. (2010). Epigenetic reprogramming in plant and animal development. Science 330: 622-627.

Frank, A. C., and Johnson, M. A. (2009). Expressing the diphtheria toxin A subunit from the HAP2(GCS1) promoter blocks sperm maturation and produces single sperm-like cells capable of fertilization. Plant Physiol 151: 1390-1400.

Ge, L., Gou, X., Yuan, T., Strout, G. W., Nakashima, J., Blancaflor, E. B., Tian, H. Q., and Russell, S. D. (2011). Migration of sperm cells during pollen tube elongation in Arabidopsis thaliana: behavior during transport, maturation and upon dissociation of male germ unit associations. Planta 233: 325-332.

Guignard, L. (1899). Sur les antherozoides et la double copulation sexuelle chez les vegetaux angiospermes. Rev. Gen. de Bot. 11: 129-135.

Hamamura, Y., Nagahara, S., and Higashiyama, T. (2012). Double fertilization on the move. Curr Opin Plant Biol 15: 70-77.

Hamamura, Y., Saito, C., Awai, C., Kurihara, D., Miyawaki, A., Nakagawa, T., Kanaoka, M. M., Sasaki, N., Nakano, A., Berger, F., and Higashiyama, T. (2011). Live-cell imaging reveals the dynamics of two sperm cells during double fertilization in Arabidopsis thaliana. Current Biology 21: 497-502.

Higashiyama, T., Kuroiwa, H., Kawano, S., and Kuroiwa, T. (2000). Explosive discharge of pollen tube contents in Torenia fournieri. Plant Physiol 122: 11-14.

Hirai, M., Arai, M., Mori, T., Miyagishima, S. Y., Kawai, S., Kita, K., Kuroiwa, T., Terenius, O., and Matsuoka, H. (2008). Male fertility of malaria parasites is determined by GCS1, a plant-type reproduction factor. Current Biology 18: 607-613.

Huang, B. Q., Fu, Y., Zee, S. Y., and Hepler, P. K. (1999). Threedimensional organization and dynamic changes of the actin cytoskeleton in embryo sacs of Zea mays and Torenia fournieri. Protoplasma 209: 105-119.

Huang, B. Q., and Russell, S. D. (1994). Fertilization in Nicotiana-Tabacum - Cytoskeletal Modifications in the Embryo Sac during Synergid Degeneration - a Hypothesis for Short-Distance Transport of Sperm Cells Prior to Gamete Fusion. Planta 194: 200-214.

Huang, B. Q., and Sheridan, W. F. (1998). Actin coronas in normal and indeterminate gametophyte1 embryo sacs of maize. Sexual Plant Reproduction 11: 257-264.

Huck, N., Moore, J. M., Federer, M., and Grossniklaus, U. (2003). The Arabidopsis mutant feronia disrupts the female gametophytic control of pollen tube reception. Development 130: 2149-2159.

Ikeda, Y., Kinoshita, Y., Susaki, D., Iwano, M., Takayama, S., Higashiyama, T., Kakutani, T., and Kinoshita, T. (2011). HMG domain containing SSRP1 is required for DNA demethylation and genomic imprinting in Arabidopsis. Dev Cell 21: 589-596.

Ingouff, M., Hamamura, Y., GourgueS, M., Higashiyama, T., and Berger, F. (2007). Distinct dynamics of HISTONE3 
variants between the two fertilization products in plants. Current Biology 17: 1032-1037.

Ingouff, M., Sakata, T., Li, J., Sprunck, S., Dresselhaus, T., and Berger, F. (2009). The two male gametes share equal ability to fertilize the egg cell in Arabidopsis thaliana. Current Biology 19: R19-20.

Kessler, S. A., Shimosato-Asano, H., Keinath, N. F., Wuest, S. E., Ingram, G., Panstruga, R., and Grossniklaus, U. (2010). Conserved molecular components for pollen tube reception and fungal invasion. Science 330: 968-971.

Knox, R. B., Zee, S. Y., Blomstedt, C., and Singh, M. B. (1993). Male Gametes and Fertilization in Angiosperms. New Phytologist 125: 679-694.

Liu, Y., Tewari, R., Ning, J., Blagborough, A. M., Garbom, S., Pei, J., Grishin, N. V., Steele, R. E., Sinden, R. E., Snell, W. J., and Billker, O. (2008). The conserved plant sterility gene HAP2 functions after attachment of fusogenic membranes in Chlamydomonas and Plasmodium gametes. Genes Dev 22: 1051-1068.

Miyazaki, S., Murata, T., Sakurai-Ozato, N., Kubo, M., Demura, T., Fukuda, H., and Hasebe, M. (2009). ANXUR1 and 2, sister genes to FERONIA/SIRENE, are male factors for coordinated fertilization. Current Biology 19: 1327-1331.

Mogensen, H. L. (1992). The male germ unit: concept, composition and significance. International Review of Cytology-a Survey of Cell Biology 140: 129-147.

Mol, R., Matthysrochon, E., and Dumas, C. (1994). The Kinetics of Cytological Events during Double Fertilization in ZeaMays L. Plant Journal 5: 197-206.

Mori, T., Hirai, M., Kuroiwa, T., and Miyagishima, S. Y. (2010). The functional domain of GCS1-based gamete fusion resides in the amino terminus in plant and parasite species. PLoS One 5: e15957.

Nawaschin, S. (1898). Resultate einer Revision der Befruchtungsvorgange bei Lilium martagon und Fritillaraia tenella. . Bull. Acad. Imp. Sci. St. Petersbourg 9: 377-382.

Pagnussat, G. C., Yu, H. J., and Sundaresan, V. (2007). Cell-fate switch of synergid to egg cell in Arabidopsis eostre mutant embryo sacs arises from misexpression of the BEL1-like homeodomain gene BLH1. Plant Cell 19: 3578-3592.

Qin, Y., Leydon, A. R., Manziello, A., Pandey, R., Mount, D., Denic, S., Vasic, B., Johnson, M. A., and Palanivelu, R. (2009). Penetration of the Stigma and Style Elicits a Novel Transcriptome in Pollen Tubes, Pointing to Genes Critical for Growth in a Pistil. Plos Genetics 5: e1000621.

Ron, M., Saez, M. A., Williams, L. E., Fletcher, J. C., and McCormick, S. (2010). Proper regulation of a spermspecific cis-nat-siRNA is essential for double fertilization in Arabidopsis. Genes Dev 24: 1010-1021.

Rotman, N., Rozier, F., Boavida, L., Dumas, C., Berger, F., and Faure, J. E. (2003). Female control of male gamete delivery during fertilization in Arabidopsis thaliana. Current Biology 13: 432-436.

Russell, S. D. (1985). Preferential fertilization in Plumbago: Ultrastructural evidence for gamete-level recognition in an angiosperm. Proc Natl Acad Sci U S A 82: 6129-6132.

Russell, S. D., and Cass, D. D. (1981). Ultrastructure of the Sperms of Plumbago-Zeylanica .1. Cytology and Association with the Vegetative Nucleus. Protoplasma 107: 85-107.

Saito, C., Nagata, N., Sakai, A., Mori, K., Kuroiwa, H., and Kuroiwa, T. (2002). Angiosperm species that produce sperm cell pairs or generative cells with polarized distribution of DNA-containing organelles. Sexual Plant Reproduction 15: 167-178.

Sandaklie-Nikolova, L., Palanivelu, R., King, E. J., Copenhaver, G. P., and Drews, G. N. (2007). Synergid cell death in Arabidopsis is triggered following direct interaction with the pollen tube. Plant Physiol 144: 1753-1762.

Slotkin, R. K., Vaughn, M., Borges, F., Tanurdzic, M., Becker, J. D., Feijo, J. A., and Martienssen, R. A. (2009). Epigenetic reprogramming and small RNA silencing of transposable elements in pollen. Cell 136: 461-472.

Sodmergen, Chen, G. H., Hu, Z. M., Guo, F. L., and Guan, X. L. (1995). Male Gametophyte Development in PlumbagoZeylanica - Cytoplasm Localization and Cell Determination in the Early Generative Cell. Protoplasma 186: 79-86.

Spielman, M., and Scott, R. J. (2008). Polyspermy barriers in plants: from preventing to promoting fertilization. Sexual Plant Reproduction 21: 53-65.

Takeuchi, H., and Higashiyama, T. (2011). Attraction of tipgrowing pollen tubes by the female gametophyte. Current Opinion in Plant Biology 14: 614-621.

Tian, H. Q., Yuan, T., and Russell, S. D. (2005). Relationship between double fertilization and the cell cycle in male and female gametes of tobacco. Sexual Plant Reproduction 17: 243-252.

Wallwork, M. A. B., and Sedgley, M. (2000). Early events in the penetration of the embryo sac in Torenia fournieri (Lind.). Annals of Botany 85: 447-454.

Wang, D., Zhang, C., Hearn, D. J., Kang, I. H., Punwani, J. A., Skaggs, M. I., Drews, G. N., Schumaker, K. S., and Yadegari, R. (2010). Identification of transcription-factor genes expressed in the Arabidopsis female gametophyte. BMC Plant Biol 10: 110.

Wolff, P., Weinhofer, I., Seguin, J., Roszak, P., Beisel, C., Donoghue, M. T., Spillane, C., Nordborg, M., Rehmsmeier, M., and Kohler, C. (2011). High-resolution analysis of parent-of-origin allelic expression in the Arabidopsis Endosperm. PLoS Genet 7: e1002126.

Wong, J. L., Leydon, A. R., and Johnson, M. A. (2010). HAP2(GCS1)-dependent gamete fusion requires a positively charged carboxy-terminal domain. PLoS Genet 6: e1000882.

Wuest, S. E., Vijverberg, K., Schmidt, A., Weiss, M., Gheyselinck, J., Lohr, M., Wellmer, F., Rahnenfuhrer, J., von Mering, C., and Grossniklaus, U. (2010). Arabidopsis female gametophyte gene expression map reveals similarities between plant and animal gametes. Current Biology 20: 506-512.

Ye, X. L., Yeung, E. C., and Zee, S. Y. (2002). Sperm movement during double fertilization of a flowering plant, Phaius tankervilliae. Planta 215: 60-66.

Received: 13 February 2012 